\title{
One hundred years of barbiturates and their saint
}

\author{
Dimitri A Cozanitis MD DTM\&H
}

J R Soc Med 2004;97:594-598

Soporifics were limited to alcohol and opium until 1869 , when chloral hydrate was first used as a sedative and hypnotic. Urethane, bromides, chlorbutanol, sulphones, hederal and chloralose then followed. In 1863, Johan Adolf Baeyer discovered malonylurea, a substance that would become the parent compound of the barbiturates. The date of this discovery is believed to have been 4 December, and on that same day Baeyer visited a tavern frequented by artillery officers. 4 December is the feast day of Saint Barbara, patron saint of artillery-men as well as tunnellers and firemen; thus he designated his malonylurea barbituric acid (Figure 1).

(4)

(3)<smiles>O=C1NC(=O)C([18OH])C(=O)N1</smiles>

off. That night Barbara armed herself with prayer and, by God's grace, her wounds were healed. She escaped and hid in a cave but a wicked shepherd betrayed her to Dioscurus who beheaded his own daughter. Immediately thereafter loud thunder was heard; Dioscurus was struck by lightning and was pulverized. ${ }^{1}$

\section{THE FIRST BARBITURATES}

In 1903, a former assistant of the now von Baeyer in Strasbourg, Emil Fischer, along with a friend since their student days, Josef von Mering, ${ }^{2}$ published their paper on a new hypnotic, barbital. ${ }^{3}$ von Mering having visited Verona earlier thought it appropriate to name a compound after the city; thereby barbital became Veronal. ${ }^{4}$ It was manufactured by E Merck in Darmstadt and was even available as scored soluble cocoa-flavoured tablets. ${ }^{5}$ The barbiturate era had begun.

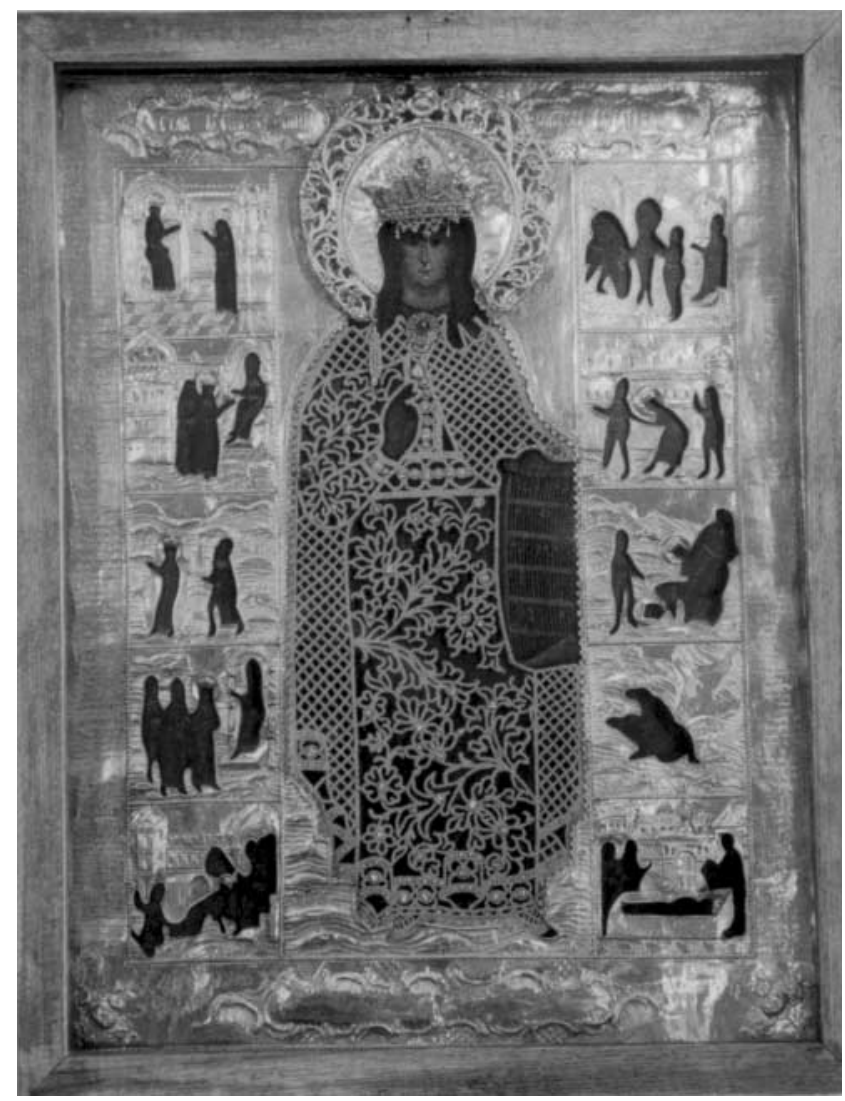

Figure 2 Icon of St Barbara (in pearl and metal), Uspenski Cathedral, Helsinki. [Photo: Mariamne Purmonen]
Department of Anaesthesiology \& Intensive Care Medicine, Institute of Clinical Medicine, Helsinki University, Finland

Correspondence to: Department of Anaesthesiology \& Intensive Care Medicine, Helsinki University Hospital, Meilahti Hospital, FIN-00290 HUS, Finland

E-mail: dcozanitis@yahoo.com

Figure 1 Barbituric acid (malonylurea)

\section{THE SAINT} to shield his daughter, whose beauty drew all eyes upon her, he confined Barbara to a tower having two windows. During one of her father's travels, she secretly embraced Christianity and had a third window added through which the sun would shine and honour the Holy Trinity. When Dioscurus returned and learned of Barbara's conversion, he drew his sword to kill her but she was miraculously saved. Dioscurus offered Barbara to the pagan Roman Governor, Marcianus, who was taken by her beauty. Unable to win her to his will (for she had devoted her life to God), Marcianus ordered that the maiden be flogged and have her breasts cut 


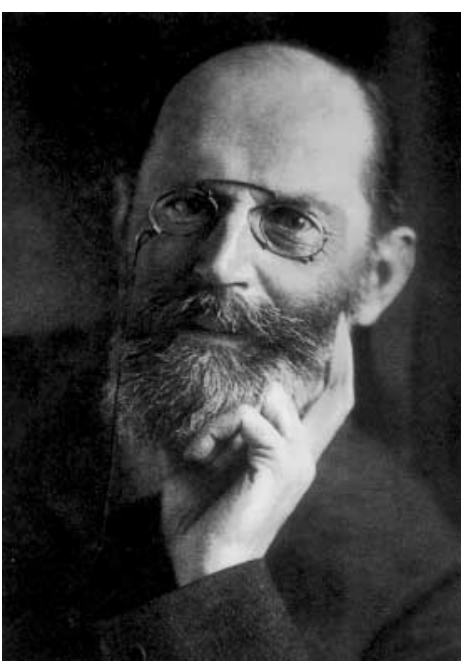

Figure 3 Emil Fischer (1852-1919). [Courtesy: Medical Historical Institute and Museum,University of Zurich]

Emil Fischer (Figure 3) came from an affluent family. His father, a lumber merchant, owned 1800 acres of prime oak forest. Rather than following in his father's footsteps, the young Fischer was drawn to chemistry. He became independently wealthy at the age of 21 and developed into an eminent scientist receiving the Nobel Prize in Chemistry, three years before his mentor von Baeyer was similarly honoured, for his studies on sugar and purine chemistry. In his autobiography Fischer mentions Veronal only in passing, since it was the synthesis of enzymes that most interested him. ${ }^{2}$ Seven of his pupils became Nobel laureates.

It was Josef von Mering (Figure 4), later to earn fame as a physiologist and pharmacologist, who persuaded Fischer to synthesize barbital. In 1886, von Mering created experimental diabetes by injecting phloridzin into dogs. Along with Oskar Minkowski in 1890 he demonstrated, by pancreatectomy, that the pancreas was the seat of insulin production.

In 1919, Heinrich Hörlein at Bayer introduced phenobarbital (Luminal). Patent rights were granted to Bayer in 1916 for yet more barbiturates, including pentobarbitone. ${ }^{6}$ When the United States entered the Great War in 1917, a serious difficulty arose since German products were now considered enemy property. To overcome this obstacle the American Government passed the Trading with The Enemy Act, which permitted the Federal Trade Commission to grant licences to American firms to manufacture German products. ${ }^{7}$

In 1923, Horace Shonle at Lilly synthesized amylobarbitone, Amytal, and six years later Amytal sodium became the first ever barbiturate to be used as an intravenous anaesthetic. The sodium ion at the $\mathrm{C} 2$ position of the barbituric acid molecule makes the barbiturates soluble for

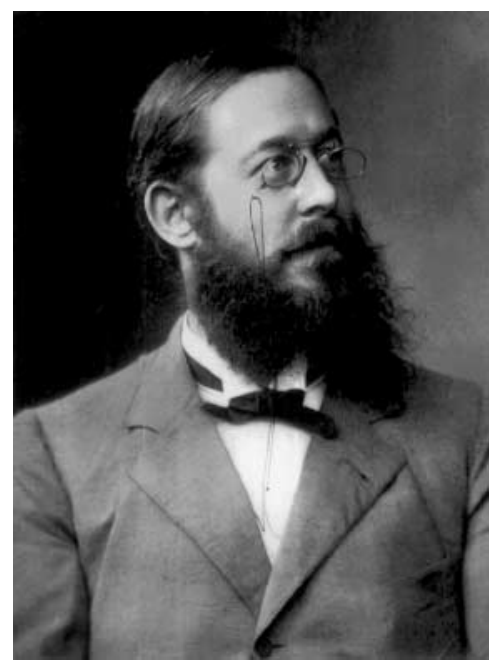

Figure 4 Josef von Mering (1849-1908). [Courtesy: Medical Historical Institute and Museum, University of Zurich]

intravenous therapy as well as affording greater absorption after oral dosage. This product however, hydrolysed within thirty minutes of its preparation and its effects were undesirably long lasting.

\section{SHORT-ACTING AGENTS}

Again in 1923, Shonle as well as Volviler and Tabern at Abbott, working independently, created pentobarbitone. Abbott was denied patent rights since these belonged to Bayer. ${ }^{6}$ Despite this, they offered their product 844 to John Lundy, anaesthetist at the Mayo Clinic, for oral clinical evaluation. The first recipients were Lundy's wife, Charles Mayo (co-founder of the Clinic) and Jack Dempsey, former world heavyweight boxing champion. ${ }^{7}$ The compound was launched as Nembutal and achieved outstanding clinical and commercial success. An intravenous preparation was also available, but had prolonged action.

The quest for an ultra-short-acting barbiturate ended in 1932 when the chemists Walther Kropp and Ludwig Taub and the pharmacologist Hellmuth Weese at IG Farbenindustrie introduced hexobarbitone (Evipan). ${ }^{8}$ Under orders of the Allied Control Council in 1945 this firm, whose scientists had discovered among other compounds the first sulfonamide (Prontosil) and methadone, ceased to exist and its executives faced trial at Nurenberg. Evipan and Evipan sodium became the property of the new Bayer company until the product was finally withdrawn from the market in mid-1992.

In 1934, Volviler and Tabern created their ultra-shortacting barbiturate thiopentone (Pentothal) by replacing the oxygen atom in the pentobarbitone molecule for one of sulphur. For their achievement they were inducted into the Inventors Hall of Fame, joining such earlier luminaries as 
Henry Ford, Thomas Edison, and the Wright brothers. ${ }^{7}$ A sad note is that misuse of Pentothal and Evipan was the cause of deaths in casualties of the Pearl Harbor attack in 1941.9

Lilly began trials with their ultra-short-acting counterpart 22451 in 1954. These were soon abandoned after reports of excessive muscular activity and even convulsions. In 1957, after further development, Lilly's now acceptable preparation emerged; methohexitone (Brietal) entered the field, having an even shorter duration of action than either Pentothal or Evipan.

Lundy again was the first to use Pentothal, in 1934. The effect of the dose of the drug was gauged by paying attention to 'respiratory exchange', rather than to respiratory movements by placing a wisp of cotton over the nose and mouth of the patient and observing its motion. Lundy also noted that morphine given subcutaneously along with a small dose of Nembutal before injecting Pentothal would enable a patient to answer questions truthfully without ever remembering being questioned. Thus he suggested that this be used 'for obtaining information from insane persons or criminals'. ${ }^{10}$ Tatum, however, was sceptical about any 'truth serum'. 11

Arthur L Tatum, with degrees in chemistry, physiology, and pharmacology before qualification in medicine, joined Abbott to evaluate Nembutal. He attempted to negotiate to receive a 2.5\% royalty for his efforts from all of Abbott's Nembutal sales, without success. ${ }^{12}$ Barbiturates were classified according to their duration of action-long, intermediate, short and ultra-short. Tatum advocated the use of analeptics, specifically picrotoxin, in the treatment of acute barbiturate toxicity; this became accepted practice until later refutation. He also discovered that barbiturates were an effective antidote for cocaine intoxication. ${ }^{11}$

The ease of substituting various groups onto the C 5-5 position of the parent molecule yielded over 2500 barbiturates worldwide. Some 60 of these were marketed, although five or six would have probably sufficed. Despite the advent of the benzodiazepines in 1961 and newer types of anticonvulsants, there remains a considerable demand for barbiturates. The 2002 edition of the American Drug Index lists single and combination barbiturate preparations in

Box 1 Examples of available preparations containing barbiturates in 2002 (Source: American Drug Index)

Amylobarbitone+d-amphetamine

Butabarbitone+aspirin, caffeine

Butabarbitone+nitroglycerin

Phenobarbitone+propanthaline

Phenobarbitone+ephedrine, theophylline

Phenobarbitone+pepsin, atropine, pancreatin, hyoscyamine

Phenobarbitone+homatropine, aluminium hydroxide,

magnesium trisilicate addition to an array of barbiturates combined with other drugs for a wide spectrum of medical conditions ${ }^{13}$ (Box 1).

The barbiturates seemed a godsend to both patients and physicians because of their apparent freedom from harmful side-effects. They endowed sleep to those deprived of it, and for others relieved the intolerable anxiety of everyday living. But these blessings came with a price; the Achilles' heel of these drugs was the development of tolerance, noted first in $1903^{5}$ and the physiological dependence on them which could lead to their misuse or abuse.

\section{CLASSIFICATION AND CONTROL}

Barbiturates were greatly sought after and easily obtainable. In 1939, 100 tonnes of barbiturates were sold in the USA. Annual production there reached 2000 tonnes by the mid1960s. As early as 1920, a notice by the Lilly sales department disclosed that 'some jobbers were ordering barbital in lots of 1000 dollars each' ${ }^{14}$ Between the World Wars, a Canadian physician remarked, 'I bought Luminal tablets in 5000 lots every few months'. ${ }^{15}$ Such statements were portents. From 1928 to 1937, of just over one million hospital admissions from ten centres, 143000 were in consequence of barbiturate intoxication; the corresponding figure from 1940 to 1945 was 200000 . New York City hospitals were reporting that one death every 36 hours was related to barbiturate misuse or abuse. ${ }^{16}$ The number of suicides involving barbiturates was second only to that resulting from carbon monoxide poisoning. Warnings were sounded by medical and pharmaceutical associations but they fell on deaf ears. If some action was taken, it was more symbolic than substantial. The American legislative process for barbiturate control was posing difficulties. In 1945, a Bill was put before Congress (HR 6178) that would place barbiturates in the category of narcotics - a move adamantly opposed by the American Pharmaceutical Association. ${ }^{17}$ Uniform State laws were believed to be less complex and drastic than Federal legislation. Unfortunately, disagreements arose among the States regarding the recordkeeping, prescription renewals, manufacturing and distribution of these compounds.

The legal aspects aside, the greatest evil was illegitimate use. For reasons of frustration, desperation, or simple foolishness, the American public was gulping barbiturates, which on the streets were easily found and cheap. They had names such as 'red birds', 'red dogs' and 'yellow jackets' (based on the colour of the capsules) or 'Nebbies', 'goof pills' or 'downers'. The gratification offered by these drugs was oblivion. Lilly's quinalbarbitone, 'Seconal' (in red capsules), was particularly popular. Lilly apart, there were some 60 providers of this substance, and tens of millions of 'reds' were imported illegally from Mexico. Lilly was accused in the press of blanketing the country with their 
barbiturates. The company fought back, limiting the number, colour, and size of the empty capsules that were sold to wholesalers. Every single item, whether capsule, tablet, box or package, would carry the Lilly identification label. Various barbiturate awareness programmes were initiated by Lilly for both health and law enforcement agencies. ${ }^{18}$

Barbiturates differ in their capacity to become habitforming and Dutta proposed a classification according to their potential for abuse. Amylobarbitone, pentobarbitone and quinalbarbitone are in the category with the highest abuse potential rating, while the ultra-short-acting compounds (e.g. hexobarbitone, thiopentone, methohexitone) possess little or no potential for abuse. ${ }^{19}$ In 1971, the US Controlled Substances Act went into effect. Under the Act, barbiturates and other drugs including narcotics are divided into five schedules according to their potential for abuse along with their application in medical practice.

Although America bore the brunt of the barbiturate issue, 1968 saw 24700000 prescriptions for barbiturates in the UK. Physicians were obviously catering more to the public's wants than to their needs. ${ }^{20}$ The Campaign for the Use and Restriction of Barbiturates (CURB) was formed by a group of determined individuals who used teaching and commercial promotional techniques to inform and educate physicians of the hazards associated with barbiturates. The Medicines Act of 1968 provided legal control over barbiturate products.

The measures taken to contain the barbiturate problem have borne fruit. The 2002 annual report of the American Association of Poison Control Centers recorded 3573 cases of barbiturate poisoning with 21 deaths. ${ }^{21}$ In 1997, there was an unusually high number of fatalities (54) involving barbiturates, with phenobarbitone and alcohol implicated in the mass suicide of 42 members of a cult.

\section{PHENOBARBITONE}

Phenobarbitone is considered a sedative rather than a hypnotic substance and according to the Controlled Substances Act grouping it has low abuse potential. In 1912, phenobarbitone (Luminal) was found effective for the treatment of epilepsy by Hauptmann in Hoche's clinic in Freiburg. It replaced the bromides which had been used for this purpose since 1857. Certainly, tolerance in patients treated with phenobarbitone did develop, but the factor of addiction was questioned. Tatum was of the opinion that addiction to barbiturates does not occur ${ }^{11}$ but others disagreed. In any case, the signs and symptoms of abstinence clearly differ between chronic users of barbiturates and those of opioids. Over time, phenobarbitone therapy for epilepsy, particularly in children, causes hyperactivity, troubles with school and sleep and impaired memory performance. ${ }^{22}$ Barbiturates are best known for their effect on the central nervous system but a peripheral effect is that provided by phenobarbitone for the treatment of physiological jaundice of the newborn. The mode of action is the induction of glucuronyl transferase and other hepatic enzymes that can be functionally immature in these infants. ${ }^{23}$

\section{CONCLUSION}

The century of barbiturates has brought benefit to some and troubles to others but still their namesake remains a source of veneration. In 1988, French tunnellers set up a statue of St Barbara at the Sangatte access shaft when work began on the Euro-tunnel. Austrian tunnellers, in 2000, working alongside British and French colleagues, placed a statuette of their patron saint in the $3.2 \mathrm{~km}$ tunnel under the North Downs and the Thames as part of the new line from the Channel coast to London. Sadly, on 31 May 2002 the cave where Barbara had been beheaded near Aboud in Palestine, and the tunnel leading to it, were severely damaged by military action. The cave had been a pilgrimage site since her death in 306. In England there are two churches dedicated to St Barbara; the older one, in Ashton under Hill, Worcestershire, is more than 1000 years old.

Acknowledgements Sincere thanks for help in preparing this article are due to Christopher C J Jones; Archivist Lisa Bayne, Eli Lilly \& Company, Indianapolis; Archivist Walter Fuchs, Medical Historical Institute and Museum, University of Zurich; and Katja Glock, Merck KGaA, Darmstadt. The reading of the manuscript by my medical colleagues is gratefully appreciated.

\section{REFERENCES}

1 The Legends of Saint Barbara. London: Royal Artillery Institution, 1955

2 Fischer E. Aus Meinen Leben. Berlin: Julius Springer, 1922

3 Fischer E, v Mering J. Ueber eine Klasse von Schlafmitteln. Ther Gegenw 1903;5:97-101

4 Winternitz H, Zuntz N. Josef v Mering. Muench Med Wschr 1908;8:400-2

5 Report of the Advancements of Pharmaceutical Chemistry and Therapeutics. Darmstadt: Merck, 1903

6 Kaiserliches Patentamt. Patent No. 293163. Issued to Farbenfabriken worm. Friedr. Bayer \& Co, 16 July 1916

7 Pratt WD. The Abbott Almanac: 100 Years of Commitment to Quality Health Care. Elmsford, NY: Benjamin, 1987

8 Henny KM. Das intravenöse Narkotikum Evipan-Natrium (Hexobarbital-Natrium) und seine Anwendung [Thesis]. RheinschWestfallischen Technischen Hochschule Aachen, 1997

9 Halford FJ. A critique of intravenous anesthesia in war surgery. Anesthesiology 1943;4:67-9

10 Lundy JS. Intravenous anesthesia: preliminary report of the use of two new thiobarbiturates. Proc Mayo Clin 1935;10:536-43 
11 Tatum AL. The present status of the barbiturate problem. Physiol Rev $1939 ; 19: 472,502$

12 Swann JR. Academic Scientists and the Pharmaceutical Industry. Baltimore: Johns Hopkins University Press, 1988

13 Billups NF. American Drug Index. St Louis: Facts \& Comparisons, 2002

14 Archives, Eli Lilly and Company, Indianapolis, IN, General letter No. 120, 28 October 1920

15 Porter R. The Greatest Benefit to Mankind. A Medical History of Humanity from Antiquity to the Present. London: Harper-Collins, 1997

16 Goldstein SW. Barbiturates: a blessing and a menace. J Am Pharm Assoc 1947;6:5-14

17 Editorial. Narcotic control of barbiturates. J Am Pharm Assoc 1946;7:240
18 Kahn Jr EJ. All in a Century-The First 100 Years of Eli Lilly and Company. West Cornwall, CN: Kahn, 1976

19 Dutta SN. Sedatives-hypnotics. In: Pradhan SE, ed. Drug AbuseClinical and Basic Aspects. St Louis: Mosby, 1977:102-15

20 Dunlop D. The use and abuse of psychotropic drugs. Proc $R$ Soc Med 1970;63:1279-82

21 Watson WA, Litovitz TL, Rodgers GC, et al. 2002 annual report of the American Association of Poison Control Centers - Toxic Exposure Surveillance System. Am J Emerg Med 2002;21:353-421

22 Breuning SE, Poling AD. Drugs and Mental Retardation. Springfield: Charles C Thomas, 1982

23 Hutchison JH. Practical Paediatric Problems. London: Lloyd-Luke, 1980 